\title{
AGARWOOD PRODUCTION- A MULTIDISCIPLINARY FIELD TO BE EXPLORED IN BANGLADESH
}

\author{
Selina Akter*1, Md. Tanvir Islam ${ }^{1+2}$, Mohd Zulkefeli ${ }^{3}$, Sirajul Islam Khan ${ }^{1}$ \\ ${ }^{1}$ University of Dhaka, Dhaka 1000, Bangladesh \\ 2Jessore Science and Technology University, Jessore 7408, Bangladesh \\ ${ }^{3}$ Atta-ur-Rahman Institute for Natural Product Discovery, Universiti Teknologi \\ MARA, Puncak Alam, Selangor, Malaysia
}

\begin{abstract}
'Agarwood' or 'eaglewood' ('Aguru' in Bengali) is the most expensive wood in the world, which is an occasional product of a few genera of Aquilaria and Gyrinops in the plant family Thymelaeaceae. Agar is a scented product, oleoresin, obtained from pathological conditions of the wood of live trees containing many aromatic substances. Various bacteria and fungi have been found to be associated with Agarwood formation, although it is still not absolutely clear which are important or even necessary. The quality of agar mostly depends on the plant species and the fungal species involved, as well as, certain other unknown factors. The issues are now to explore the new sources of agarwood to protect the endangered plant species, to ensure agar formation in $100 \%$ of the planted trees, upgrade in quality and most possibly quantity of agar yield per tree simultaneously minimizing the maturation time. Both physical and chemical stresses like mechanical wound and induction have long been practiced to enhance agarwood yield as well as fungal inoculation. Specificity of fungal infection is a minor criterion of agarwood formation rather than the plant's physiological state, immune responses and presence of inducer. The agarwood production could be a multifaceted field of prospects in Bangladesh. The cultivation of new Aquilaria and Gyrinops plants and selection of appropriate inocula and inducers should be the priority objective. A multidisciplinary approach could be initiated with the experts of forestry, mycology, biochemistry and microbiology to achieve the goal.
\end{abstract}

Keyword: aquilaria, agarwood, artificial induction, fungi, perfumery

\section{Agarwood}

'Agarwood' or 'oodh' (or just agar) is dark resinous heartwood that forms in Aquilaria and Gyrinops (Blanchette, 2006) trees in the plant family Thymelaeaceae. The heartwood is relatively light and pale coloured; however, as the wood matured (a term used in general sense), the tree produces a dark aromatic resin in response to infection or unknown induction, which results in a very dense, dark, resin embedded heartwood. The resin embedded wood is commonly called gaharu, agarwood, or oud and is valued in many cultures for its distinctive fragrance, and thus is used as incense and perfumes. Agarwood is known under many names in different cultures; In Hindi, it is known as agar, which is originated from Sanskrit aguru. The Sanskrit name aguru is directly used in Bengali (Bouverie, 1885), Telugu and Kannada. It is known as chénxiāng in Chinese, trầm hương in Vietnamese (Thứ Hai, 2006), and jinkō in Japanese- all meaning "sinking incense". In Japan, there are several grades of jinkō, the highest of which is known as kyara (Kiyoko, 2007). 
Both agarwood and its resin distillate/extracts are known as oud in Arabic (Tony, 2005) Western perfumers also use agarwood essential oil under the name "oud" or "oude" (Nathan, 2009). In Europe it was referred to as Lignum aquila (eagle-wood) or Agilawood (Henry and Coke, 1903). Another name is Lignum aloes or Aloeswood (Henry and Coke, 1903). In Tibetan, it is known as a-ga-ru. There are several varieties used in Tibetan medicine: unique eaglewood- ar-ba-zhig; yellow eaglewood- a-ga-ru ser-po, white eaglewood- ar-skya, and black eaglewood- ar-nag (Yuri et al, 1992). In Assamese it is called as "sasi" or "sashi"(panda, 2009). The Indonesian and Malay name is "gaharu"(Henry and Coke, 1903). In Papua New Guinea, it is called "ghara" or eaglewood. In Thai language, it is known as "Mai Kritsana". In Tamil it is called "akil" and in Laos it is known as "Mai Ketsana" (Seng et al., 2005).

\section{The tree of concern}

There are fifteen species in the genus Aquilaria and eight are known to produce agarwood ( $\mathrm{Ng}$ et al., 1997). In theory agarwood can be produced from all members; however, until recently it was primarily produced from $A$. malaccensis, $A$. agallocha and $A$. secundaria (Broad, 1995). A. crassna and $A$. sinensis are the other two members of the genus that are usually harvested. At least fifteen species of Aquilaria trees are known to produce the much sought-after Agarwood. In South Asia, Aquilaria achalloga and Aquilaria khasiana are found, particularly in India. Aquilaria malaccensis is mostly known from Malaysia, Indonesia and India, and Aquilaria crassna principally grows in Cambodia, Malaysia, Thailand, and Vietnam. Aquilaria apiculina was found in Philippines, Aquilaria acuminata in Papua New Guinea, Indonesia and Philippines, Aquilaria baillonil in Thailand and Cambodia, Aquilaria baneonsis in Vietnam, Aquilaria beccariana in Indonesia, Aquilaria brachyantha in Malaysia, Aquilaria cumingiana in Indonesia and Malaysia, Aquilaria filaria in New Guinea, the Moluccas, and Mindanao (Philippines) (NPGS/GRIN, 1), Aquilaria grandiflora in China, Aquilaria hirta in Thailand, Indonesia and Malaysia (NPGS/GRIN, 2), Aquilaria microcapa in Indonesia and Malaysia, Aquilaria rostrata in Malaysia, Aquilaria sinensis in China, and Aquilaria subintegra grows in Thailand. Aquilaria sp. is fast-growing, archaic tropical forest tree, which occurs in South and Southeast Asia, from the foothills of the Himalayas to the rainforests of Papua New Guinea. The tree grows in natural forests at an altitude of a few meters above sea level to about 1000 meters, and it grows best around 500 meters in locations with average daily temperatures of 20 to 22ㅇ (Afifi, 1995; Keller and Sidiyasa, 1994; Wiriadinata, 1995). Aquilaria sp. has adapted to live in various habitats, including those that are rocky, sandy or calcareous, well-drained slopes and ridges and land near swamps. It is a large evergreen tree, growing over $15-40 \mathrm{~m}$ tall and 0.6-2.5 $\mathrm{m}$ in diameter, and has white flowers (Chakrabarty et al., 1994; Sumadiwangsa, 1997). Trees grow very fast, and start producing flowers and seeds as early as four years old.

\section{Agarwood history}

Formation of agarwood occurs in the trunk and roots of trees that have been infected by parasites. As a response, the tree produces a resin high in volatile organic compounds that aids in suppressing or retarding the infection, a process called tylosis. While the unaffected wood of the tree is relatively light in colour, the resin dramatically increases the mass and density of the affected wood, changing its colour from pale beige to dark brown or black. In natural forest, only about $7 \%$ of the trees are infected by fungus. Ascomycetous mold, Phaeoacremonium parasitica (Crous et al., 1996), a dematiaceous (dark-walled) fungus is one of the known fungi reported to be associated with agarwood formation. The odour of 
agarwood is complex and pleasing, with few or no similar natural analogues. As a result, agarwood and its essential oil gained great cultural and religious significance in ancient civilizations around the world, being mentioned throughout one of the world's oldest written texts - the Sanskrit Vedas from India. As early as the third century AD in ancient China, the chronicle 'Nan zhou yi wu zhi' (Strange things from the South) written by Wa Zhen of the Eastern Wu Dynasty mentioned agarwood produced in the Rinan commandery, now Central Vietnam, and how people collected it in the mountains. Xuanzang's travelogues and the Harshacharita, written in seventh century AD in Northern India, mentions use of agarwood products such as 'Xasipat' (writing material) and 'aloe-oil' in ancient Assam. The tradition of making writing materials from its bark still exists in Assam. The use of agarwood for perfumery extends back several thousand years, and is referred, for example, in the Old Testament several times using the term 'aloes'. Agarwood has been used for medicinal purposes for thousands of years, and continues to be used in ayurvedic, Tibetan and traditional East Asian medicine (Chakrabarty et al., 1994; Fratkin, 1994). The Sahih Muslim, which dates back to approximately the eighth century, refers to the use of agarwood for the treatment of pleurisy and its use is referred in the ayurvedic medicinal text the Susruta Samhita. The "Wood of the Gods" has been traded and highly appreciated for thousands of years. The resinous wood or oil extracted is extremely valuable since it is highly regarded for use during Buddhist and Islamic cultural activities, as well as, an important ingredient in many traditional medicines. It is also an extremely important component in traditional Japanese incense ceremonies. Although most people in the United States and Europe are not familiar with this aromatic resinous wood, its use as incense is mentioned several times in the bible. Outside native countries, it is most widely known in the Middle East, China, Taiwan and Japan. A strong connection exists between use, religion and curative properties, and elaborate traditional and religious ceremonies are known from around the world. Faith healers in the Middle East use it at curative ceremonies, Japanese pilgrims donate flowers and agarwood oil to Shinto-Buddhist temples, and Vietnamese religious groups are obliged to bring agarwood to ceremonies at their temples in Mekong delta communities.

\section{Agarwood uses}

Agarwood is extremely highly valued by luxury perfume, fragrance and soap manufacturers. Both agarwood smoke and oil are customarily used as perfume in the Middle East (Chakrabarty et al., 1994). In India, various grades of agarwood are distilled separately before blending to produce final 'attar'. Minyak attar is a water-based perfume containing agarwood oil, which is traditionally used by Muslims to lace prayer clothes (Yaacob, 1999). Agarwood perfumes are seldom pure agarwood oil, but instead use an alcoholic or nonalcoholic carrier, such as sandalwood oil. Agarwood essences have also been used as a fragrance in soaps and shampoos (Kadir et al., 1997, cited in Schippmann, 1999). Perfumist Kim Weisswange, assigned by the British royal family to create a perfume for William and Kates marriage, worked on the fragrance for seven weeks mixing over 90 ingredients. Two of the main notes that stand out in this ensemble are Norfolk lavender and agarwood (Agarwood news, 2011). The leading luxury brands such as Yves St. Laurent, Dior, Juicy Couture and others all make heavy use of oud oil in their premium brands. Agarwood is prescribed in traditional East Asian medicine to promote relieve pain, arrest vomiting by warming the stomach, and to relieve asthma (Anon, 1995). High-grade agarwood powder is prescribed in Chinese medicine (Yaacob, 1999) and is also used in the production of pharmaceutical tinctures (Beek and Phillips, 1999). Burkill (1966) reported that Malaysians used agarwood mixed with coconut oil as a liniment, and also in a boiled concoction to treat rheumatism and other body pain. Chakrabarty et al. (1994) reported that the often-discarded uninfected wood is used as 'Kayugaharu lemppong' by Malaysians to treat jaundice and body pains. Agarwood is also prescribed for dropsy as a carminative, a stimulant for heart 
palpitations, and as a tonic taken particularly during pregnancy, after childbirth and for diseases of female genital organs (Chakrabarty et al., 1994).

Agarwood incense is burned to produce a pleasant aroma, its use ranging from a general perfume to an element of important religious occasions. Irregular chunks of agarwood are burned in a specially made incense burner (Beek and Phillips, 1999). Agarwood powder and dust is used to make incense sticks or coils for indoor fragrance, and are used for religious purposes by Muslims, Buddhists and Hindus (Yaacob, 1999). Taiwanese consumers purchase agarwood for the manufacture of incense sticks, which are used in prayers during many traditional festivals and ceremonies to bring safety and good luck (TRAFFIC East AsiaTaipei, 2000). Both Indians and Chinese have used agarwood as an essential ingredient of incense sticks in the past, but in the present day incense sticks generally do not contain agarwood, although Indian traders report that high-quality Indian incense sticks destined for export may have a drop of agarwood oil added to them (Chakrabarty et al., 1994). Agarbattis are incense cones, which also originally contained agarwood powder but seldom; do so now because of the high price of agarwood. Japanese incense products are very different, with most of the highest-grade products made using natural raw materials, which include ground agarwood extracts combined with other ingredients such as sandalwood and benzoin and then carefully molded and baked. Pure agarwood is also burned as incense in Japan. In Malaysia, Muslims burn agarwood splinters or chips to produce incense during special religious occasions, particularly at gatherings, and agarwood incense has been recorded in use there during Ramadan prayers (Chakrabarty et al., 1994). Agarwood incense is used for various purposes in the Middle East, especially during prayers (Yaacob, 1999). Agarwood chips and splinters are also burned in bathrooms and incense is used as a customary perfume.

\section{Economic values}

The value of first-grade agarwood is extremely high. A whole range of qualities and products is on the market varying with geographical location and cultural deposition. Prices range from a few dollars per kilo for the lowest quality to over thirty thousand US dollars for top quality oil and resinous wood. Agarwood chips start at £20 per kilo up to $£ 6,000$ per kilo depending on how much resin is inside the chips. First-grade agarwood is one of the most expensive natural raw materials in the world. Agarwood oil fetches similarly high prices (Agarwood "Wood of Gods" International Conference, 2003). Likewise, the oud oil distilled from agarwood can cost as much as $£ 20,000$ per kilogram depending on the purity of the oud oil. The current global market for agarwood is estimated to be in the range of US\$ $6-8$ billion and is growing rapidly. For an outlay of $£ 20,000 / \cup S \$ 32,000$, expected return is approximately $£ 65,600 / U S \$ 104,000$ at the conclusion of 7 year with an Internal Rate of Return of approximately $29 \%$. Arabian oud association plans to unveil the largest oud shop of the world in Riyadh along with a museum to mark celebrated classics in their collection. The Arabian oud franchise has spread over the Saudi kingdom, and is sweeping across Western Europe. Agarwood cannot be synthesized. Chemical substitutes are already available for perfume but do not come even close in mimicking the natural product. The major chemical components responsible for the characteristic scent of agarwood products, sesquiterterpenes, can in principle be synthesized. However, these are very complicated structures that will be extremely expensive to synthesize, which makes it commercially completely unattractive. 


\section{Aquilaria, a threaten plant species}

One of the reasons for the relative rarity and high cost of agarwood is the depletion of the wild resource (Broad, 1995). Since 1995, Aquilaria malaccensis, the primary source, has been listed in Appendix II (potentially threatened species) by the Convention on International Trade in Endangered Species of Wild Fauna and Flora (CITES, 2005). Overharvesting and habitat loss threatens some populations of agarwood-producing species. Aquilaria crassna is now listed as a protected species in Viet Nam, and Aquilaria malaccensis is a CITES red data book listed tree. Aquilaria trees are now protected in most countries and the collection of agarwood is illegal from natural forests. International agreement, such as CITES, accepted by 169 countries, is designed to ensure trade in agarwood products from wild trees does not threaten the survival of Aquilaria. Despite these efforts, agarwood products from illegally cut trees continues to be sold and unknowing consumers create a demand that helps to destroy the last old growth Aquilaria trees in existence. Trade and harvesting restrictions will be virtually impossible to achieve if no alternative is developed to forest-based harvesting. In addition, both in the short and long-term, a natural resource base needs to be maintained to supply present and future Aquilaria plantations with genetic source material, in order to prevent plant decease, maintain diversity and possibly improve resin production. Another, more recent way of producing agarwood, is to grow trees in plantations. Agarwood plantations have been established in a number of countries including Bangladesh, Bhutan, India, Indonesia, Laos, Malaysia, Myanmar, Papua New Guinea, Thailand and Vietnam. Luxury brands concerned with their image are willing to pay a premium for agarwood's oud oil, sourced from sustainable Aquilaria plantation forests.

\section{Bangladesh perspectives}

Considering its conservation value and economic benefit, BRAC has started agarwood plantation in Bangladesh at Kaiyachara Tea Estate from July, 2007 (Akter and Neelim, 2008). At Kaiychara tea estate, a plantation of about 17 acres has been created, where 83,400 agar seedlings have been planted between August and October 2007. In addition, 700,000 agar seedlings have been planted in two nurseries, namely 'Kaiya' and 'Sirgasia', at Kaiyachara tea estate. Initially, the BRAC tea estate plans to plant 50 acres of land with agar plant, after which agarwood harvesting would take place after 12 years. Assuming 90\% survival rate and $2 \mathrm{~kg}$ premium quality agarwood production per plant, the estimated investment related to plantation would be Tk. 145,497,198 and total return would be Tk. $60,907,155,348$ with the rate of return $41,861 \%$. However, this high rate of return is an underestimate given the environmental benefits of this plantation would generate. The establishment of this plantation would also be significant in terms of the environmental conservation of this endangered species, as well as, provide a carbon sink to reduce green house gases. Furthermore, there are potential opportunities that would arise in the future for improving the livelihoods of poor people in the region by providing income generating means. In an addition, several reports have been come up with small scale and personal agarwood plantations in Sylhet, Habiganj and Chittagong Hill Tracks.

\section{Agarwood plantation and induction}

In addition to the fact that only $1 \%$ of Aquilaria trees contain the resinous agarwood substance, the Aquilaria since 1995 has been protected by the Convention of International Trade in Endangered Species of Wild Fauna and Flora due to massive and ongoing illegal logging. Luckily, the plantation involved in Thailand involved in the agarwood project has created a unique process by which the agarwood resin can be created inside every Aquilaria tree on their plantation. This means that agarwood timber investments satisfy a global 
consumer need whilst not contributing in any fashion to the destruction of tropical forests. There are many beliefs on how agarwood is formed and these views have strongly been wrapped in myth and history. Only in the last few decades, more scientific approaches have been conducted. Scientists with assistance from the locals have tried to understand the mechanism involved in the formation of agarwood and conduct research based on their understanding. Experiments involve laboratory works and setting-up demonstration plots have been established in some countries, including China, Thailand, Indonesia, India and Cambodia. Approach in these studies is generally done by wounding trees deliberately with different treatments to induce agarwood formation. The success of agarwood plantation depends on the stimulation of agarwood production in the trees. Numerous inoculation techniques have been developed, with varying degrees of success ( $\mathrm{Ng}$ et al., 1997). A diagrammatic representation of induction practices has been illustrated in Figure 1, which are commonly adopted by the indigenous people and fellow researchers.
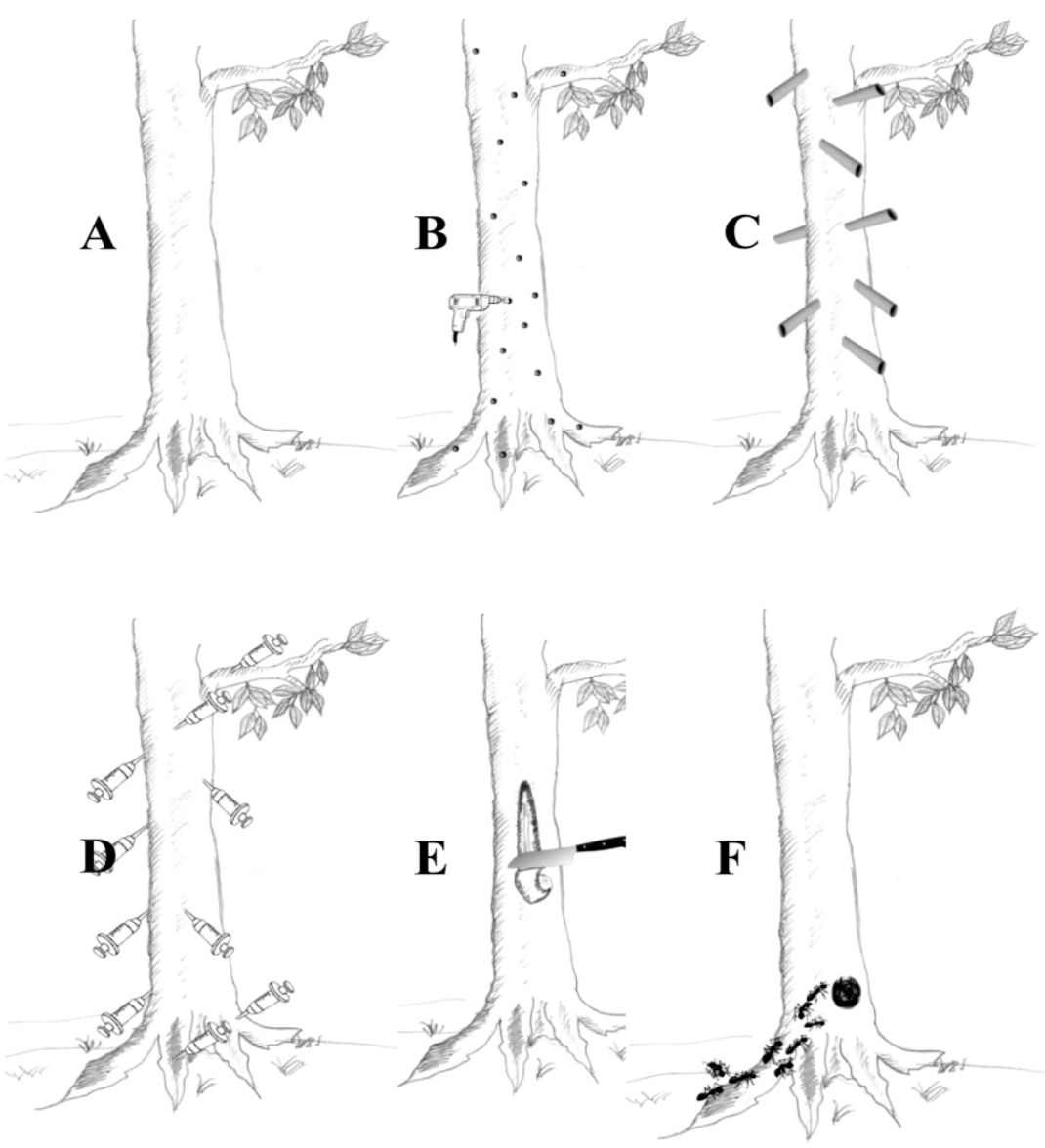

Figure 1: Illustration of induction methods commonly used in agarwood formation. In natural maturation process, no induction or injury is required but need years to achieve considerable amount of resin synthesis (A). General practice of artificial induction is to drill the stems, roots and large brunches (B). The drilled pores were kept open to ease access of natural agents into the pores. Addition of sugary syrup or inocula to these pores attracts insects and facilitates infection. Metal or PVC tubes were installed in those pores (C) to prevent healing the pores and establish prolonged infection. Syringe with inocula and inducers (D) were also used to assist batch and continuous inoculation and induction. In some region, indigenous people peel off the bark (E) to promote infection to the core tissues and harvest the chips of woods 
seasonally from live tree. There are certain areas where a hole was dug in the tree to facilitate hatching of ants and snails (F), which is being believed to be responsible for agarwood formation.

A drill is usually employed to make holes in the trunks and main branches of mature trees which are then inoculated with resinous agarwood powder. Generally, agarwood is harvested when the trees are between five and ten years old. Agarwood resin forms in response to a still somewhat mysterious set of factors. In the past, it was thought to be an insect infestation. Recent experiments involve deliberate wounding of the tree, injecting it with an irritating substance, and preventing it from healing naturally. This is somewhat effective, producing some infected wood, but has not been so successful with oil as an oil produced from young and farmed trees is lower quality, hard and "greasy." The best agarwood, when an entire tree is infected with high quality, dense resin and oil, can occur only with plenty of time, and preferably in the forest or other non-contrived setting. This tree will also be dead or dying and sometimes partly buried. It has long been known that the production of the fragrant resin is associated with wounding and associated fungal invasion, possibly assisted by insects. As a response to the fungal infection, the tree produces a resin high in volatile organic compounds that aids in suppressing or retarding the growth of the fungus. Various fungi are associated with agarwood formation although it is still not completely clear which one makes the plant generate the resin. Three hypotheses exist regarding agarwood formation, namely that it is the result of pathological, wounding/pathological and/or nonpathological processes ( $\mathrm{Ng}$ et al., 1997) but studies have not provided conclusive evidence for any of these hypotheses. Oldfield et al. (1998) states that resin production is in response to fungal infection, and Beek (2000) said that it is in response to wounding. The author also adds that fungal infection can increase resin production as a host response to increased damage due to fungal growth. Aquilaria trees are naturally infected by a variety of fungi including: Aspergillus spp., Botryodyplodia spp., Diplodia spp., Fusarium bulbiferum, F. laterium, F. oxysporum, F. solani, Penicillium spp., and Pythium spp. (Anon., 1998; Soehartono and Mardiastuti, 1997; Wiriadinata, 1995). However, the ecological interaction between the host tree and the wound and/or the fungi in order to produce agarwood is poorly understood. Other factors, such as, the age of the tree, differences in the tree caused by seasonal variation, environmental variation and genetic variation of Aquilaria spp. may also play an important role in agarwood formation ( $\mathrm{Ng}$ et al., 1997). Not all Aquilaria trees produce agarwood; Gibson (1977, cited in $\mathrm{Ng}$ et al., 1997) estimated that only approximately $10 \%$ of wild Aquilaria spp. produces resin. Gianno (1986, cited in La Frankie, 1994) suggested that only one-tenth of mature trees produce agarwood. According to Chakrabarty et al., (1994), infected trees produce resin from the age of 20 years onwards; Sadgopal (1960, cited in Soehartono and Mardiastuti, 1997) suggested that the best yields are obtained from trees aged 50 years and over. Recent studies undertaken by The Rainforest Project (TRP) in Vietnam have shown that agarwood formation can occur in cultivated trees as young as three years of age, as confirmed by chemical analysis (Beek, 2000). The yield and qualities of the resinous agarwood also vary considerably (Hartadi, 1997; $\mathrm{Ng}$ et al., 1997; Oetomo, 1995; Wiriadinata, 1995). Research conducted in West Kalimantan Indonesia, shows that the yield of Aquilaria resin does not correspond with tree diameter or timber volume, even when trees have similar indications of infection (Soehartono and Mardiastuti, 1997). Gianno (1986, cited in La Frankie, 1994) suggested that those trees above $20 \mathrm{~cm}$ diameter at breast height (dbh) that produced agarwood provided approximately one $\mathrm{kg}$ of agarwood per tree. However, a recent discovery from the University of Minnesota has revolutionized the agarwood production. Through a method of inoculation of specific chemicals, the rate of agarwood formation is increased. The patent right document prepared claims that agarwood production through the use of this inoculation increases to 30 percent as opposed to the 7 percent that occurs naturally and more importantly this inoculation can be done at an younger age than that mentioned above. What triggers agarwood to form in some old trees 
has been an unsolved mystery. A research investigation over 12 years in cooperation with The Rainforest Project Foundation, a nonprofit organization dedicated to the preservation of the world's forests (http://www.agarwood.org.vn), has studied the formation of resin in Aquilaria and Gyrinops trees and found a method to produce the resin in plantation grown young trees. The technique consists of wounding trees in a specific manner and applying treatments to accelerate the natural defense responses of the tree. The technique allows a sustainable yield of resin to be produced in relatively young trees. A field trip to the top of Nui Giai mountain provided the participants of the 'First International Agarwood Conference' the opportunity to see Aquilaria trees growing in plantations and to view the results of our agarwood inducement techniques.

Wounding agarwood tree using blade or hammering of nails into the trunks has been used widely in the past, however agarwood yielded from this treatment is generally of inferior quality and cannot meet the desired market demand (Persoon, 2007). However, agarwood hunters in Papua New Guinea deliberately wounded agarwood trees in an attempt to stimulate agarwood production and reported that they were able to harvest agarwood of $B$ and $C$ grades, three years after this treatment (Gunn et al., 2003). Pojanagaroon and Kaewrak (2005) investigated various mechanical methods in stimulating agarwood formation including making a holes with screws, wounding using chisels, and bark removal with hatchets. Methods of injury had influenced in agarwood formation and somewhat determined by seasonal changes, rainy season accelerated agarwood formation faster. Another effort involves drilling of trees and keeping the wound open by placing a small piece of plastic pipe in those holes followed by a chemical injection to stimulate tree defense mechanism that produces resin. It was initiated in Vietnam under supervision of Prof. Robert Blanchette. This artificial induction could yield agarwood ten times faster than natural formation (http://forestpathology.coafes.umn.edu). This finding has gained appreciation and has been considered as one of the most successful findings (Persoon, 2007). This treatment causes tree to respond both physical and chemical defense mechanisms. In Thailand, similar experiment was conducted and established agarwood plantation. Krissana Panasin company in Chantaburi in Southeast Thailand, has established agarwood plantation of several hundred hectares. Similar project has been established in Merauke, Papua, Indonesia by a Catholic Church and in Papua New Guinea, which involves trials of numerous methods to treat the trees. The formation of agarwood is also a result of plant defense mechanism towards fungal attacks by producing resinous compounds as secondary metabolite. Many scientists have been passionately trying to understand the cascade process of this tree-fungi interaction in producing agarwood. Isolation of various fungi from infected trees has been widely reported. The finding of novel technology to accelerate agarwood formation based on this mechanism continues to sprout and research has become more intensive. Torula sp. has been successfully used in $A$. agallocha and found to accelerate agarwood formation. The treatment stopped in 1931 due to inoculum's contamination. Use of Cladosporium sp. and Epicoccum granulatum was conflicting. Pencillium citrinum, Aspergillus tamari, Fusarium solani, Fusarium oxysporum Schlect, Fusarium tricinctum, Fusarium xylaroides, Botryodiplodia spp., Theobromae spp., Philophora parasitica, Epicoccum sp., Chaetum globosum Kunze, Cylindrocarpon were frequently isolated in A. agallocha. Botryodiplodia theobromae, Curvularia lunata, Fusarium oxysporum and Pestalotia sp. were parasitic whereas Cercosporella sp., Chaetomium spirale, Cladosporium sp., Phialogeniculata sp., Pithomyces sp., Rhizopus sp., Spiculostibella sp. and Trichoderma sp. were saprophytic to Aquilaria spp. found in Thailand. A group of Mataram University, Indonesia found that $F$. lateritum could be isolated and cultured in potato dextrose agar (PDA) media and that the fungi could form agarwood after 2-month injection to 4-year-old trees. Artificial induction of five to seven years old Gyrinops versteegii trees in Mataram and twelve Aquilaria spp. in Pekanbaru, Sumatra by drilling holes and inoculating with five Fusarium spp. including Fusarium trifosfrium, which has been described by Tabata et al. (2003). The results showed that agarwood was observed around the drilled sites but uninoculated trees also formed agarwood. A combination of $2 \%$ sugar solution, Acremonium sp. and methyl jasmonate was 
reported to produce agarwood of kemedangan quality class IV, where wood discoloration, fragrance level, and terpenoids contents were independent criteria in determining agarwood quality (Yunita, 2009). The first trial for artificial induction in Indonesia was conducted by injecting five fungal-producing agarwood: Botryodiplodia sp., Fusarium oxysporum, $F$. bulbigenium, F. laseritium, and Phytium sp. on a total of 300 trees of 8-year-old $A$. microcarpa. Before injection, palm sugar and lubricant were added and mixed with the fungi. This preliminary study showed that the formation of agarwood was improved by the addition of palm sugar and lubricant. The three Fusarium species formed larger area of agarwood on the infected trees. After three months, agarwood formation was indicated by stem cracking and the skin was easily torn. The infected part of stem is fragrant when it was burnt confirming that agarwood was formed. Novel findings by Santoso et al. (1996) have revealed important aspects that determine the successful of agarwood formation by artificial induction, i.e. methods of injection, fungal strain type, and growing media for delivering the fungi. Molecular identification of 36 strains of agarwood inducing fungi collected from 17 provinces in Indonesia revealed that all the isolates were members of Fusarium spp, mostly $F$. solani. Communities in northern Vietnam cut a hole in the trunk or main branches of Aquilaria trees. If the wound is kept open by regular chipping, agarwood generation may be induced after several years and can be extracted in nominal quantities each time when chipped, as long as the tree remains alive. This method may be adapted and further developed as "tapping" of agarwood, and may be a more sustainable alternative to felling the entire tree. Another technique took the wounding a step further by plugging the wound with a piece of wood or pottery shard. This prevents the wound from closing and therefore would seem to be a more reliable method for inducing agarwood production. A method of coppicing by indigenous Penan people is reported from Borneo (Donovan and Puri, 2004). Although harvest quantities are small, the trees develop a dense coppice and provide continuous yield. The periodic coppicing wounds the trees and promotes further formation of agarwood. In laboratory analysis, salicylic acid and methyl jasmonate were added to calli and suspension cell culture respectively, in order to induce production of fragrant compounds. Both induced production of three sesquiterpenoids, $\alpha$-guaiene, $\alpha$-humulene, and $\delta$-guaiene at early stage of treatment but did not induce that of chromone derivatives directly.

\section{Conclusion}

Though, specificity of fungal infection is a minor criterion of agarwood formation rather than the plant's physiological state, immune responses and presence of inducers, an approach should be taken immediately to search and optimize perfect inoculums and inducers. In recent days, Aquilaria trees have attracted attention for its economic values and rarity. The agarwood production could be a multifaceted field of prospects in Bangladesh. The hilly barren area of the country could be transferred to goldmine. Several NGOs and private owned forests have been investing for Aquilaria plantation in several districts in Bangladesh. But the success of the effort largely depends on the agarwood yield. Artificial induction is not a new story but yet to be made known andavailable in the country. This is the time to think about investing on research of induction to achieve economic goal of plantation. The venture needs devotees to expertise sourcing new plants, selection of inocula and induction. A multidisciplinary approach could be initiated with the experts of forestry, mycology, biochemistry and microbiology to achieve the goal.

\section{References}

1. Afifi (1995). Proses pengolahan pohon gaharu sampai siap diperdagangkan dan tata cara pembudidayaannya, serta proese gaharu pembentukan gubal. In:Lokakarya Pengusahaan Hasil Hutan Non. 
2. Agarwood news (2011). Agarwood used in Prince Williams wedding fragrance; http://www.agarwoodnews.com/2011/07/agarwood-used-in-prince-williams.html.

3. Akter, N. and A.Z. Neelim (2008). Agarwood Plantation at BRAC Tea Estate: Introduction, Environmental Factors and Financial Analysis. BRAC Research Report.

4. Anon (1995). A Coloured Atlas of the Chinese Materia Medica Specified in Pharmacopoeia of the People's Republic of China (1995 Edition). Pharmacopoeia Commission of the Ministry of Public Health, P.R. China. Joint Publishing (H.K.) Co., Ltd., Honk Kong.

5. Aquilaria filaria information from NPGS/GRIN

6. Aquilaria hirta information from NPGS/GRIN

7. Beek, Heuveling van H and D. Phillips (1999). Agarwood: Trade and CITES mplementation in Southeast Asia. Unpublished report prepared for TRAFFIC Southeast Asia, Malaysia.

8. Blanchette, R.A. (2006). The genus Gyrinops, is closely related to Aquilaria and in the past all species were considered to belong to Aquilaria. "Cultivated Agarwood - Training programs and Research in Papua New Guinea", Forest Pathology and Wood Microbiology Research Laboratory, Department of Plant Pathology, University of Minnesota.

9. Bouverie, P.E. (1885). Daniel the Prophet: Nine Lectures, Delivered in the Divinity School of the University of Oxford, Funk \& Wagnalls, New York, p. 515.

10. Branch, N. (2009). "Dawn Spencer Hurwitz Oude Arabique (extrait)" (fashion and fragrance reviews).

11. Broad, S. (1995). Agarwood harvesting in Vietnam, TRAFFIC Bulletin, 15:96.

12. Burfield, T. (2005). "Agarwood Trading" The Cropwatch Files, Cropwatch.

13. Burkill, I. (1966). A Dictionary of Economic Products of the Malay Peninsula, I. Government of Malaysia and Singapore. The Ministry of Agricultural and Cooperatives, Kuala Lumpur.

14. Chakrabarty, K., A. Kumar and V. Menon (1994). Trade in Agarwood. In: Barden, A., A.A. Noorainie, T. Mulliken, and M. Song (2000). Heart of the matter: Agarwood use and trade and CITES implementation for Aquilaria malaccensis. TRAFFIC International.

15. CITES (2005) "Notification to the Parties" No. 2005/0025.

16. Crous, P. W. et al. (1996). Phaeoacremonium gen. nov. associated with wilt and decline diseases of woody hosts and human infections, Mycologia 88(5): p. 786-796.

17. Donovan, D. and R. Puri. (2004). Learning from traditional knowledge of non-timber forest products: Penan Benalui and the autecology of Aquilaria in Indonesian Borneo. Ecology and Society 9(3): p. 3.

18. Fratkin, J. (1994). Chinese Herbal Patent Formulas: A Practical Guide. Shya ublications, Colorado, USA, p. 356.

19. Gianno, R. (1986). The exploitation of Resinous Products in a lowland Malayan forest. Wallaceana, 43: p. 3-6.

20. Gibson, I. (1977). The Role of Fungi in the Origin of Oleoresin Deposits (Agaru) in the wood of Aquilaria Agallocha Roxb, Bano Biggyan Patrika, 6(1): p. 16-26.

21. Gunn, B., P. Stevens, M. Singadan, L. Sunari and P. Chatterton (2003). Eaglewood in Papua New Guinea. Resource Management in Asia-Pacific (RMAP), Working Paper No. 51. First International Agarwood Conference, 1-15 November 2003, Tropical Rainforest Project, Viet Nam.

22. Hartadi, I. (1997). The hunt for gaharu. Conservation Indonesia.

23. Henry, Y. and A. C. Burnell (1903). "Eaglewood" Hobson-Jobson: A Glossary of Colloquial Anglo-Indian words and Phrases, and of Kindred Terms, Etymological, Historical, Geographical and Discursive (2nd edition) John Murray, London, p. 335.

24. Kadir, A.A., L.T. Ng and Y.S. Chang (1997). A review on agar (gaharu) producing Aquilariaspecies. Journal of Tropical Forest Products 2(2): p. 272-285.

25. Keller, P. and K. Sidiyasa (1994). Trees of Balikpapan-Samarinda Area, East Kalimantan, Indonesia. In: Barden, A., A. A. Noorainie, T. Mulliken and M. Song (2000). Heart of the 
matter: Agarwood use and trade and CITES implementation for Aquilaria malaccensis. TRAFFIC International.

26. La Frankie, J. (1994). Population dynamics of some tropical trees that yield non-timber forest products. Economic Botany, 48(3): p. 301-309.

27. Morita, K. (2007). The Book of Incense: Enjoying the Traditional Art of Japanese Scents. Kodansha USA.

28. Ng, L.T., Y.S. Chang and A.A. Kadir (1997). A review on agar (gaharu) producing Aquilaria species, Journal of Tropical Forest Products 2(2): p. 272-285

29. Oldfield, S, C. Lusty, and A. MacKinven (1998). The Word List of Threatened Trees. World Conservation Press, Cambridge, UK, p. 650.

30. Panda, H. (2009). Aromatic Plants Cultivation, Processing And Uses. National Institute of Industrial Re., p. 182.

31. Persoon, G.A. (2007). Agarwood: the life of a wounded tree, IIAS Newsletter, 45: p. 2425.

32. Pojanagaroon, S, C. Kaewrak (2005). Mechanical methods to stimulate aloes wood formation in Aquilaria crassna Pierre ex H. Lec. (kritsana) trees. Acta Hortic, 676: p. 16166.

33. Sadgopal (1960). Explanatory studies in the development of essential oils and their constituentsin aromatic plants. Part 1: Oil of Agarwood. SPC, 33: p. 41-46.

34. Schippmann, U. (1999). Medicinal Plants Significant Trade Study: CITES Project S-109. Unpublished report, p. 88.

35. Seng, H.N. and M. Maodee (2005). Marketing and Domestication of NTFPs in North Phonsali Three Districts, NPADP Presentation, NTFP MIS Workshop Luangprabang, North Phongsali Alternative Development Project, United Nations Office on Drugs and Crime.

36. Sumadiwangsa, S. (1997). Kayu gaharu komoditi elit di Kalimantan Timur. Duta Rimba. Juli- Augustus, p. 205-206.

37. Soehartono, T and A. Mardiastuti (1997). The current trade in gaharu in West Kalimantan. Jurnal IImiah Biodiversitas Indonesia, 1(1).

38. Tabata, Y., E. Widjaja, T. Mulyaningsih, I. Parman, H. Wiriadinata, Y. I. Mandang, and T. Itoh. (2003). Structural survey and artificial induction of aloeswood, Wood Research, 90: p. 11-12.

39. Thứ Hai (2006) "kỳ nam và trầm hương" Tuổi Trẻ Online

40. TRAFFIC East Asia-Taipei (2000). in litt. to TRAFFIC International1, 2 May 2000

41. Wiriadinata, H. (1995). Gaharu (Aquilaria spp.) Pengembangan dan Pemanfaatan yang Berkelanjutan. In: Lokakarya Pengusahaan Hasil Hutan Non Kayu (Rotan, Gaharu, dan Tanaman Obat).

42. Yaacob, S. (1999). Agarwood: Trade and CITES Implementation in Malaysia. Unpublished report prepared for TRAFFIC Southeast Asia, Malaysia.

43. Yunita, L. (2009). Effectivity of Acremonium sp. and Methyl Jasmonate to Improve Agarwood Quality of Aquilaria microcarpa. IPB Scientific Repository, Bogor agricultural university. http://repository.ipb.ac.id/handle/123456789/14803

44. Yuri, P., G. Dorje and F. Meyer (1992). Tibetan medical paintings: illustrations to the Blue beryl treatise of Sangye Gyamtso (English edition of Tibetan text \& paintings), Serindia, London, 2: p. 1653-1705. 